\title{
THE ROLE OF THE INDONESIAN WOMAN'S MOVEMENT IN THE REFORM OF THE ISLAMIC FAMILY LAW OF INDONESIA
}

\author{
By: Khoiruddin Nasution
}

Abstrak

Artikel ini merupakan laporan penelitian tentang peran gerakan wanita. Indonesia dalam upaya proses lahirnya UU No. 1 tahun 1974 tentang Perkawinan. Studi ini menggunakan pendekatan sejarah, dengan sumber sejumlah buku dan tulisan yang berisi data sejarah tentang proses lahirnya UU Perkawinan. Berdasar data sejarah, sesuai dengan hasil penelitian ini, menunjukkan bahwa peran yang dimainkan sejumlah organisasi wanita Indonesia demikian penting dalam proses lahirnya UU Perkawinan. Dengan ungkapan lain, tuntutan untuk diadakan pembaruan di bidang perkawinan juga datang dari sejumlah gerakan wanita di Indonesia. Dengan demikian hasil penelitian ini menunjukkan bahwa tuntutan terhadap UU Perkawinan datang dari lapisan bowah masyarakat, di antaranya adalah kaum wanita, bukan dari tingkat atas, pemerintah, sebagaimana yang diteorikan sejumlah orang.

تناول الباحث حول ظاهرة حر كة النساء في إندونيسيا ودورها في تقــنين قانون الزواج رقم ا لعام ع 19 ا. وكان الكاتب في دراسته يأخذ منهج التاريخي في تحليل المصادر الأولية ـ وتشير النتيجة إلى أن المنظهات النساثية دورا هاما في إصلاح تانون الزواج في إندونيسيا بل أبعد من هذا إلى أن ضرورة تقنين الزواج آنذاك من متطلبات البحتمع وليس اليس

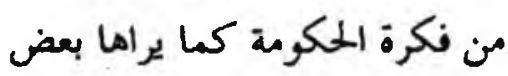
الباحثين.

Keywords: Woman's Movement, Reform, Islamic Family Law

\footnotetext{
- A Lecturer at the Faculty of the Islamic Law, and chairman of the Department of Islamic Law of Graduate Program of the State Institute of Islamic Studies (IAIN) Sunan Kalijaga Yogyakarta..
} 


\section{A. Introduction}

霣in recent years, three of the main targets of the Indonesian women's movement, which began its campaign to improve the status of women in 1900, are the issues of polygamy, (enforced) child marriage, and divorce (the one-sided right

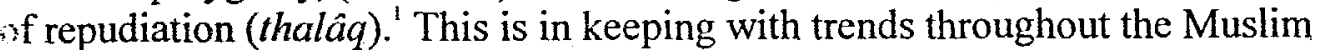
world, evidenced in the Arab Women's Conference in Kuwait in December 1972, where demands to abolish child marriage were voiced. ${ }^{2}$ Also, in Morocco in the mid- to late 1980s, a group of women struggling for equality procured the creation of a number of non-governmental organizations. ${ }^{3}$

The birth of the Indonesian feminist movement is said to date back to the 1900 's, since it was intimately allied to the national awakening. ${ }^{4}$ Furthermore, Raden Ajeng Kartini, who lived from 1879 to 1904, was the first woman to privately demand the emancipation of women. However she was principally concerned with improving women's participation by means of education, such as learning household duties, dress-making classes, course of child welfare, and the like. ${ }^{5}$ Rohana Kudus in Minangkabau, West Sumatra, ${ }^{6}$ was the first woman who privately and directly criticized the bad effects of child marriage, polygamy and one side divorce (thalâq).?

The demand to improve the status of women was then followed by a number of Indonesian women's movements, such as the Indonesian Women's Congress (Kongres Perempoean Indonesia: 'Kowani') in $1928,{ }^{8}$ the female section of Jong Java, Puteri Indonesia, with the help of a number of associations such as

\footnotetext{
'June S. Katz \& Ronald S. Katz, 1978, "Legislating Social Change in a Developing Country: The New Indonesian Marriage Law Revised", The American Journal of Comparative Law, vol. 26, p. 316.

"Arab Report and Record 1972; 2, as quoted by White, "Legal Reform as an Indicator of Women's Status," in Lois Beck and Nikki Keddie, 1978, Women in the Muslim World, Cambridge, Massachusetts: Harvard University Press, p. 54-55.

${ }^{3}$ Fati Ziai, 1997, "Personal Status Codes and Women's Rights in the Maghreb," in Mahnaz Afkhami and Erika Friedl, Muslim Women and the Politics of Participation: Implementing the Beijing Platform, Syracuse: Syracuse University Press, p. 74.

${ }^{4}$ See Cora vreede-de Stuers, 1960, The Indonesian Woman: Struggle and Achievements, Netherlands: Mouton \& Co., Printers, p. 15-16.

${ }^{5}$ Ibid.,p. 64.

${ }^{6}$ Barbara N. Ramusack and Sharon Sievers, 1988, Women in Asia, Indianapolis, Indiana University Press, p. 100. Rohana Kudus began writing articles for journals, which were eventually collected by her husband and father in a book entitled Sunting Melayu (Malayan Headdress). One of the areas that concerned her most was the negative effect on women of polygamy. In his book The Indonesian Woman, Stuers gives 1900 as the year of Rohana Kudus's birth. Some sources confirm this, others contradict it. Deliar Noer, for example, gives December 31. 1900 as her birthday, whereas Jeanne Cuisinier records it as 1903. See Cora Vreede-de Stuers, "The Life of Rankayo Rohmah El-Yunusia: The Fact and the Image," in Elsbeth Locher-Scholten and Anke Niehof, eds., 1987, Indonesian Women in Focus: Past and Present Notions Dordrecht:Foris Publications, p. 52, 57.

? Stuers, The Indonesian Woman, p. 53.

${ }^{8}$ Arso Sosroatmodjo and A. Wasit Aulawi, 1978, Hukum Perkowinan di Indonesia (The Marriage Law in Indonesia), Jakarta, Bulan Bintang, p. 9; S. Hanifa, "The Law of Marriage and Divorce in Indonesia," Islamic and Comparative Law Quarterly, vol. 3, No. 1 (March, 1983), p. 19. The congress was conducted in Yogyakarta from December 22 to 26,1928 , and included presentations by nearly thirty women's associations. See Stuers, The Indonesian Woman, p. 89.
} 
Persaudaraan Isteri (association of wives), Persatuan Ibu (association of mothers) and Wanita Sejati (genuine women), which organized a public meeting in Bandung, West Java, on October 13,1929. The subject of this meeting was to discuss polygamy and prostitution. Another example was the women's organization, Isteri Sedar, which held its first congress in Jakarta in June 1931, and adopted resolutions that amounted to a call for the abolition of polygamy.'

It is often said that the reform of Muslim family law in the Muslim world came from above (government) not from below, as stated, for example, by Anderson:

In the early days, dating from about the middle of the last century, the impu'se for reform came not from below but from above. It was not that ordinary Muslims, generally speaking were dissatisfied with the law to which they were subject and began to demand its reform, but that these reforms were imposed on them by the government. ${ }^{10}$

This appears not to hold true for Indonesian Muslim family law. Historical sources show that the reform of Indonesian Muslim family law was a positive response to demands from within Indonesian society, particularly from reform groups and women's movement, even though it is equally true that some voices from within society opposed the reform. This paper gathers the historical evidence to prove that the reform of Indonesian Muslim family law came not from government but from below, from the people. The paper will be divided into four sections. After an introduction, there will follow in the second part a historical survey of Islamic family law in Indonesia. The third section is concerned with the historical facts surrounding the demands for reform of Indonesian family law. The conclusion will summarize the points made in the body of this study.

\section{B. An Historical Survey of Indonesian Islamic Family Law}

The first marriage law promulgated in the independence period was Law No. 22 of 1946, the law on marriage, divorce and reconciliation $\left(r u j u^{\prime}\right)$. This law, promulgated on February 1, 1947, was at first applicable only in Java and Madura. Later, by way of Law No. 32 of 1954 (promulgated on November 2 that year), it was extended to the whole of Indonesia. Aulawi has stated that, theoretically, Law No. 22/1946 should have applied to all of Indonesia from the start, but that this was seen as impractical, hence the limitation to Java and Madura only. "Wirjono identifies a third, intermediate, step in the application of the first Indonesian marriage law, which he finds in the extension of the law on

\footnotetext{
'Nurlena Rifai, 1993, "Muslim Women in Indonesia's Politics: an Historical Examination of the Political Career of Aisyah Aminy," Montreal: Master's Thesis in Islamic Studies at McGill University, p. 32.

${ }^{10}$ Norman Anderson, 1976, Law Reform in the Muslim World. London: The Athlone Press, pp. 14-15.
} 
Jane 16,1949 to Sumatera, based on a Decision of Contemporary of the Republic of Indonesia (Pemerintah Darurat Republic Indonesia) on June 14, 1949 (No. 1/PDRI/KA). ${ }^{12}$

In any case, Law No. 22 of 1946 was actually a continuation of Stbl. No. 198/1895, and was designed to replace Huwelijks Ordonantie Stbl. No. 348/1929, Stbl. No. 467/1931 and Vorstenlandse Huwelijks Ordonantie Stbl. No. $98 / 1933 .^{13}$

Law No. 22/1946 consists of seven articles, and principally concerns itself with two matters. First of all it concerns the compulsory registration of marriage, divorce and reconciliation ( $r u j u)$, and secondly, provides regulation of the administrators who register such matters. According to Aulawi, although the Law explicitly regulated only administrative matters, and not the substance of marriage law, ${ }^{14}$ implicitly it obliged the administrator to determine whether all the substantive requirements had been fulfilled, and hence the administrator was required to involve himself in the substance of Islamic law itself. ${ }^{15}$

Law No. 22 of 1946 was eventually followed by Law No. 1 of 1974, enacted on January 2, 1974, which was then followed by a. Regulation on its implementation drawn up on April 1, 1975, and implemented on October 1, $1975^{16}$

Law No. 1 of 1974 consists of 14 chapters containing 67 articles, divided as follows:

- Chapter I : Basis or foundation of marriage (arts. 1-5)

Chapter II : :Pre-requisites for marriage (arts. 6-12)

Chapter III : Prevention of marriage (arts. 13-21)

ChapterIV :Dissolution of marriage (arts. 22-28)

ChapterV : Marriage agreement (marriage contract)(art. 29)

\footnotetext{
"A. Wasit Aulawi, "Sejarah Perkembangan Hukum Islam di Indonesia," (History of Islamic Law in Indonesia) in Amrullah Ahmad, (ed.), 1996, Dimensi Hukum Islam dalam Sistem Hukum Nasional (Islamic Law among National Laws). Jakarta: Gema Insani Press, p. 57; Achmad Roestandi, "Prospek Peradilan Agama (Sutu Tinjauan Sosiologis)," (The Prospect of Islamic Court in Sociological Perspective), in Amrullah Ahmad (ed.), Dinamika Hukum Islam, p. 210.

${ }^{1} \mathrm{R}$. Wirjono Prodjodikoro, 1974, Hukum Perkawinan di Indonesia (The Marriage Law in Indonesia), Bandung: Penerbit Sumur, p. 50.

${ }^{13}$ In the consideration of the Law No. 22/1946 Vorstenlausche Huwelijksordonnantie Buitengeweswesten Stbl. No. 482/1932 was also listed, see the consideration of Law No. 22/1946, art. 1. In contrast, in the Stbl. itself no explanation was given. Wirjono stated that the Law No. 22/1946 only changed two of the earlier Dutch laws, Stbl. No. 348/1929 and Stbl. No. 98/1933. See Wirjono Prodjodikoro, Hukum Perkawinan, p. 50.

${ }^{14}$ Wasit Aulawi, op.cit., p. 57-58; Mark Cammack, Lawrence A. Young and Tim Heaton, 1996, "Legislating Social Change in an Isiamic SocietyIndonesia's Marriage Law", The American Journal of Comparative Law, vol. 44 , p. 45.

"Wasit Aulawi, op.cit., p. $57-58$.

${ }^{16}$ Government Regulation No. 9 of 1975.
} 
Chapter VI : Rights and responsibilities of spouses (husband and wife) (arts. 30-34)

Chapter VII ～: Property acquired during marriage (arts. 35-37)

Chapter VIII : Dissolution of marriage and its consequences (arts. 38-41)

Chapter IX : Position of children (arts. 42-44)

Chapter X. : Right and the responsibilities of parents and children because of repudiation (arts. 45-49)

Chapter XI : Guardianship (arts. 50-54)

Chapter XII : Miscellaneous provisions (arts. 55-63)

Chapter XIII : Transitional provisions (arts. 64-65)

Chapter XIV : Final provisions (arts. 66-67).

This Law (No. 1 of 1974) was followed by Government Regulation No. 9 of 1975, and then by two decisions of the Ministers of Religious Affairs and Home Affairs. For Muslims they were superseded by the Decisions of the Minister of Religious Affairs No. 3 of 1975 and No. 4 of 1975, which were in turn replaced by Decision of the Minister of Religious Affairs. No. 2 of 1990. For nonMuslims, on the other hand, the aforementioned laws were replaced by Decision of the Minister of Home Affairs No. 221a of 1975, which regulated the registration of marriage and divorce in civil office. ${ }^{17}$

Government Regulation No. 9 of 1975 consists of 10 chapters containing 49 articles, divided as follows:
Chapter I
: General (art. 1)
Chapter II
: Registration of marriage (arts. 2-9)
Chapter III : Procedure of marriage (ceremony) (arts. 10-11)
Chapter IV : Certificate of marriage (arts. 12-13)
ChapterV : Procedure of divorce (arts. 14-36)
Chapter VI : Nullification of marriage (arts. 37-38)
Chapter VII $\quad \because$ Waiting period ('iddah) (art. 39)
Chapter VIII : Multiple wives (Polygamy) (arts. 40-44)
Chapter IX : Final provision (art.45)
Chapter X : Closing (arts. 46-49)

Another Government Regulation (Peraturan Pemerintah/PP) saw the light of day in the early 1980s as No. 10 of 1983, and it was a special Government Regulation on marriage and divorce applicable to civil servants only. This Regulation, enacted on April 21, 1983, consists of 23 articles. General speaking

\footnotetext{
${ }^{17}$ Ichtijanto S.A., "Prospek Peradilan Agama sebagai Peradilan Negeri dalam Sistem Politik Hukum di Indonesia," (The Prospect of Islamic Court to the Civil Court in Political Laws in Indonesia), in Amrullah Ahmad, (ed.), Dimensi Hukum Islam, p. 185.
} 
it deals with five main areas: (1) the definition of a civil servant; (2) the sefinition of who are to be considered to be civil servants; (3) justifications for divorce for the civil servant and related individuals; (4) justifications and requirements for civil servants and related individuals wishing to practice volygamy; and (5) the requirements for women civil servants and related individuals to become co-wives.

Government Regulation No. 10 of 1983 was then renewed in 1990 with a new Government Regulation No. 45 of 1990. This Regulation, amended on September 6,1990, consisted of only two articles.

The enactment of PP. No. 10 of 1983 was at the request of Dharma Wanita (Official Sisterhood). ${ }^{18}$ Even though the number of wives of high-ranking officials of Dharma Wanita was small, they were fairly influential. They claimed that their organization had received nany complaints from members about their husbands' behavior with regard to divorce, polygamy and lack of financial support. As a result, the organization demanded a law to protect the wives of civil servant from the practices of polygamy and divorce. ${ }^{19}$

In 1989 Law of the Islamic Court No. 7 of 1989 was passed. The Bill was proposed with the assent of the President of the Republic of Indonesia on December 3, 1988, and was ratified by Parliament on January $28,1989 .{ }^{20}$ The law, which was amended on December 14, 1989, consisted in general of regulations on the Islamic court, including the court's organization, decisions and judicial procedure. In Chapter IV, where court procedure is explained, and particularly Part Two concerning marriage procedure (arts. 65-88), there is discussion of the issue of marriage and the procedure of divorce. Thus even thought the law was directed towards regulating Islamic court procedure in general, it also affected specific aspects of Islamic marriage law. ${ }^{21}$

At the end of 1991 another regulation was introduced. Called the Kompilasi Hukum Islam di Indonesia (KHI) (the Compilation of Islamic Law in Indonesia), it was intended to regulate marriage, inheritance and donation (waqf) in the Muslim community. The regulation was amended by Instruction of the President No. 1 on June 10,1991, which was then followed by Decision of the Ministry of Religious Affairs No. 154 of 1991.

The section concerning marriage in the Compilation of Islamic Law in Indonesia consists of 19 chapters containing 170 articles, arranged as follows:

\footnotetext{
${ }^{18}$ Dharma Wanita is an organization that collects together the wives of civil servants.

${ }^{19}$ Julia I. Suryakusuma, "The State and Sexual in New Order Indonesia," in Laurie J. Sears, ed., 1996, Fantasizing The Feminine in Indonesia. Durham \& London: Duke University Press, p. 103-104.

${ }^{20}$ See the welcoming of the government of Republic Indonesia for the agreement of Parliament concerning the Islamic court, on December 14, 1989, p. XI.

${ }^{21}$ Law No. 7 of 1989 consisted of 7 chapters and 108 articles, divided as follows: I. General Provisions (arts. 1-5), II. Structure of the Islamic court (arts. 6-48), III. Authorities of the Islamic court (arts. 49-53), IV. Procedure of judging a matter (arts. 54-91), V. Miscellaneous Provisions (arts. 92-105), VI. Transitionai Provisions (arts. 106), and VII. Final Provisions (arts. 107-108).
} 


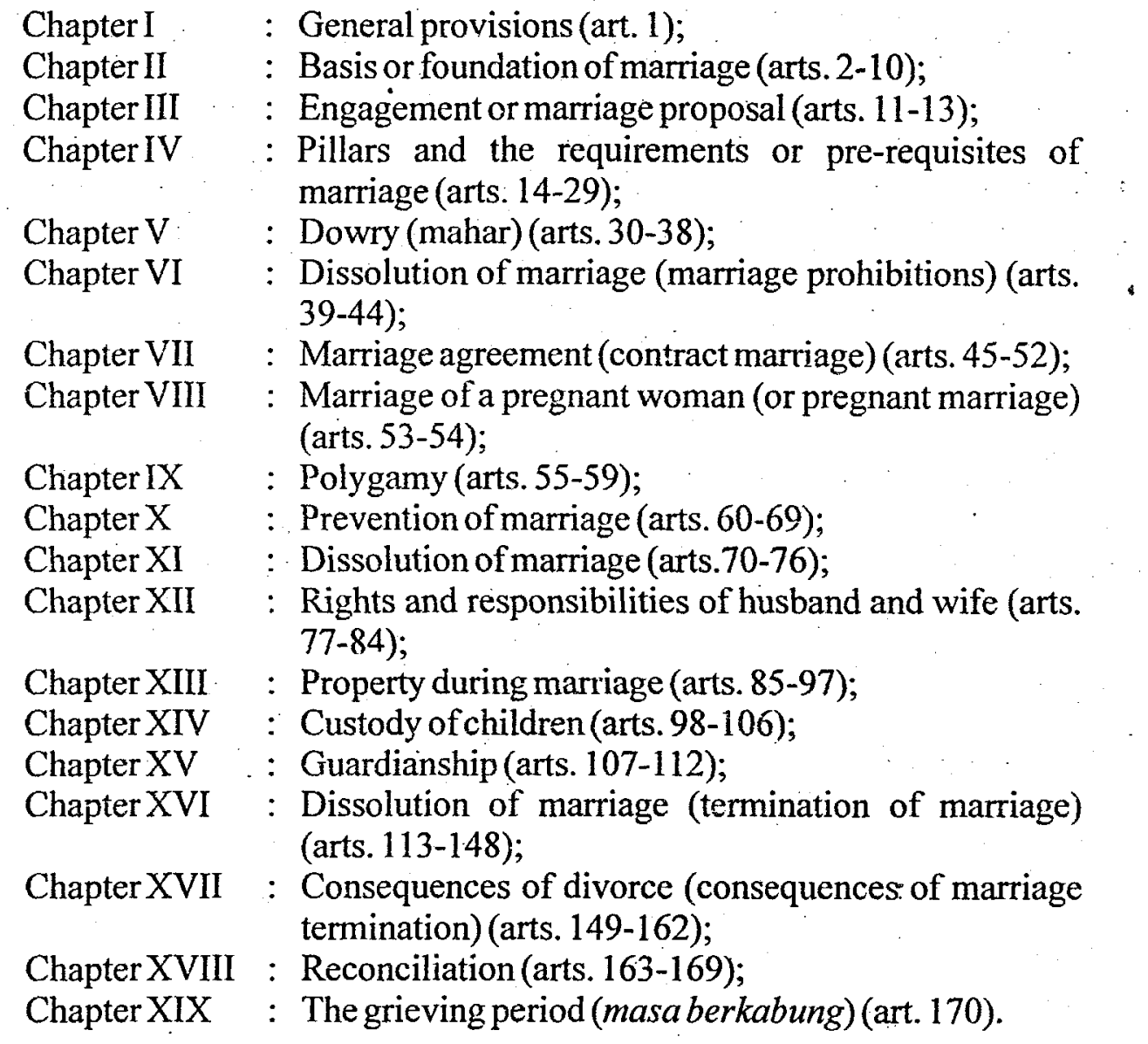

There were four main sources for the compilation of Islamic law in Indonesia: (1) the views of Indonesian Islamic scholars ('ulamấ); (2) a number of Islamic law books (figh); (3) the jurisprudence of the Islamic court of Indonesia; and (4) comparative studies of a few Muslim countries, ${ }^{22}$ in this case Morocco, Turkey and Egypt. ${ }^{23}$

The relevance of $f i q h$ and Indonesian jurisprudence (1) and (3) in forming the Compilation is obvious; the former amounts to the Islamic jurisprudence developed throughout the history of the Muslim world, and the latter amounts to the Indonesian developments of Islamic law by Indonesian judges. The reason

\footnotetext{
"Bustanul Arifin, 1996, Pelembagaan Hukum Islam di Indonesia: Akar Sejarah, Hambatan dan Prospeknya (Institutionalization of Islamic Law in Indonesia). Jakarta: Gema Insani Press, p. 59-60; idem., "Pentadbiran Undang-Undang Islam di Indonesia," (Administration of Islamic Law in Indonesia), in Ahmad Mohamed Ibrahim and Abdul Munir Yaacob, (ed.), 1997, The Administration of Islamic Laws, Kuala Lumpur: Institute of Islamic Understanding Malaysia (IKIM), p. 119.

${ }^{23}$ The study was conducted by $\mathrm{H}$. Masrani Basran, SH and H. Mucktar Zarkasyi, SH, during October and November 1986. See Bustanul Arifin, "Pentadbiran Undang-Undang Islam", p. 120-121.
} 
for the consultation of the Indonesian scholars (2): 'ulamâ was the belief that they were well-informed about Indonesian tradition, culture and context, which actors were relevant since the application of Islamic teachings is influenced by the culture or context in which the teachings are applied. The comparative zpproach (4) aimed at understanding how other Muslim countries respond to contemporary issues and problems in applying family law. ${ }^{24}$

Examining these sources in more detail, according to one commentator the reference to Islamic law books $(f i q h)$ involved thirty-eight different texts:

1. Hashiyat Kifâyat al-Akhyâr by Ibrâhîm ibn Muhammad al-Bâjûrî (d. 1227/1860)

2. Fathal-Mu'în by Zainuddîn al-Malîbârî (ca. 975 AH.)

3. Sharqawi 'alâ al-Tahrîr by 'Alî ibn Hijâzi ibn Ibrâhîm al-Sharqawî ( 1150/1737)

4. Mughnîal-Muhtâj by Muhammad al-Sharbînî(977/1569-70)

5. Nihâyat al-Muhtâj by al-Ramlî (w.1004/1595-6)

6. Al-Sharqawî 'alâ al-Hudûd by 'Alî ibn Hijâzi ibn Ibrâhîm al-Sharqawî $(1150 / 1737)$

7. I'ânat al-Tâlibîn by Sayyid Bakri al-Dimyâtî (1893)

8. Tuhfat al-Muhtâj by Shihabuddîn Ahmad ibn $\mathrm{H}$ \{ajar al-H\{aytamî (973/1665-6)

9. Targhîb al-Mushtâq by Ibn Hajar al-Haytami

10. Bulghat al-Sâlik by Ahmad ibn Muhammad al-Sâwî(1825-6)

11. Al-Farâ'id by Syamsûrî

12. Al-Mudawwanah al-Kubrâ by Shahnûn ibn Sa'îd al-Tanûkhî (854)

13. Kanz al-Râghibîn wa Syarhuhu by Jalâluddîn Muhammad al-Mahallî (d.864H.)

14. Fath al-Wahhâb by Abû Yahyâ Zakarîyâ al-Anshârî (926/1520)

15. Bidâyat al-Mujtahid wa Nihâyat al-Muqtasid by Ibn Rushd (1126-1198)

16. Al-Umm by Muhammad ibn Idris al-Shafi'î (767/8-820)

17. Bughyat al-Mustarshidîn by Husayn al-'Alawî

18. Aqîdah wa al-Sharî'ah by Mahmûd Shaltût(1893-1963)

19. Al-Muhalla by 'Alî ibn Muhammadibn Hazm (994-1064)

20. Al-Wajizz by Abû Hâmid al-Ghazâlî(1058-1111)

21. Fath al-Qadîr 'Alâ al-Hidâyah by Muhammad ibn 'Abd al-Wâhid alSiwasî (1457)

22. Kitâb al-Fiqh 'alâ al-Madzânỉ al-Arba'ah by 'Abd al-Rahmân al-Jazînî (1882-1941)

23. Fiqhal-Sunnah by Sayyid Sabiq

24. Kashfal-Qinâ' 'an Tadmín al-Sanâ'i by Ibn Rahhal al-Madânî (1727-8)

25. Majmû' Fatâwâ ibn Taymiyah by Ahmad ibn Taimîyah (1263-1328)

\footnotetext{
${ }^{24}$ Bustanul Arifin, op.cit, p. 58-60.
} 
26. Qawânîn al-Syar'îyah li Ahl al-Majâli al-Hukumîyah wa al-Iftaîyah by Sayyid 'Uthmân ibn Yahyâ (1882-1913), known as Betawi (i.e., of Jakarta, [Batavia] Indonesia)

27. Al-Mughni by 'Abd Allâh ibn Ahmad ibn Qudâmah (1147-1223)

28. Hidayah Sharh Bidâyat al-Mubtadî by 'Alî ibn Abî Bakar al-Marghinânî (1196)

29. Qawânîn al-Syar'îyah by Sayyid 'Abdullâh ibn Sadaqah San'an/Dakhlan

30. Mawâhib al-Jalîl by Muhammad ibn Muhammad Hattâb (1497-1547)

31. Hashiya al-Radd al-Mukhtâr by Muhammad Amin ibn 'Umar ibn Abidîn (1252/1836)

32. Al-Miwwatta by Mâlik ibn Anas (795)

33. Hashiyya al-Dasûqi 'alâ al-Sharh al-Kabîr by Ibn 'Arafah al-Dasûqi (1815)

34. Badâi' al-Sanâi' fi Tartîb al-Sharâi' by Abû Bakar ibn Mas'ûd al-Kâsânî (1191)

35. Tabyîn al-Haqâiq by Mu'înuddîn ibn Ibrâhîm al-Farâhi (811/1408)

36. Al-Fatôwa al-Hindîyah by al-Shaikh Nizam and other 'ulamâ'

37. Fath al-Qadîr by Muhammad ibn Ahmad al-Safatî al-Zaynabî (12441828)

38. Nihâyat al-Zayn by Muhammad ibn'Umar al-Nawâwî (1298)

Another commentator cites forty one books. Since the author does not provide a list, it is impossible to verify the claim. ${ }^{25}$

In directing the survey of these law books, the committee for the project devised a set of questions to be resolved by seven of the Institutes of Islamic studies (IAIN) by reference to these books. ${ }^{26}$

With regard to the views of Indonesian Islamic scholars ('ulama) there.were 166 'ulamâ' representing both Islamic organizations and independent scholars, especially the heads of the pesantrens. The interviews were conducted both individually and collectively. ${ }^{27}$

Regarding the comparative study, the reason for choosing Morocco, Turkey and Egypt as comparators were various. Morocco followed the Mâliki's school; Turkey, though a secular state, followed the Hanafite school; Egypt, despite of

\footnotetext{
${ }^{35}$ See Atho Mudzhar, 1993, Fatwa-fatwa Majelis Ulama Indonesia: Sebuah Studi tentang Pemikiran Hukum Islam di Indonesia, 1975-1988 (The Fatwas of MUI of Indonesia), ed. Dwibahasa. Jakarta: INIS, p. 39.

${ }^{36}$ The seven mentioned IAINs are IAIN Syarif Hidayatullah Jakara, IAIN Sunan Kalijaga Yogyakarta, IAIN Sunan Ampel Surabaya, IAIN Ar-raniri Banda Aceh, IAIN Antasari Banjarmasin, IAIN Alauddin Ujungpandang, and IAIN Imam Bonjol Padang. The limitation of these seven IAINs is based upon the letter of cooperation work between the Minister of Religious Affairs and the Rectors of the IAINs, dated on March 19, 1986. See Abdurrahman, 1995, Kompilasi Hukum Islam di Indonesia (Compilation of the Islamic Law in Indonesia), 2nd. edn.. Jakarta: AKAPRES, p. 39.

${ }^{27}$ Hasan Basri, 1986, "Perlunya Kompilasi Hukum Islam (The Necessity of the Compilation of Islamic iaw)," Mimbar Ulama No. 104/x (April 1986), p. 61..
} 
its geographical position between Morocco and Turkey, adhered to the Shâfi'ite shool. ${ }^{28}$ Ahmad Imam Mawardi has raised the question as to why no country where the Hanbalite school prevailed was chosen for this study. ${ }^{29}$ We have no answer to this question.

In the Compilation, it is stated that the basis for the compulsory registration of marriage, thalâq and ruju', was to be takhshîsh al-qadhâ, siyâsah syari' $a h$ and analogy (qiyâs) on the basis of Qur'an (2):282, idzâ tadâyantum bi daynin ilâ ajal al-musammâ fa uktubûhu. As far as polygamy was concerned, it was to be based on a reinterpretation of Qur'an (4):3, and related to Qur'an (4):129 and siyâsah syarî'ah. The concern for the minimum age of marriage was inspired by the opinion of al-Syaukâni, who stated that the case of 'Â'isyah marriage was an exception. The abolition of the $i j b a \hat{r},{ }^{30}$ was based upon the view of $\mathrm{Ibn}$ Shubrumah. Lastly, in the case of divorces has to be in the court was pursued on the basis of the views of Zhâhiri and Syî'ah Imâmîyah, which was ruled that divorce could proceed in the presence of two just witnesses. ${ }^{31}$

The aim of the Indonesian Compilation of Islamic Law was the unification of the law, and the simplification of jicicial application of the law by the creation - of one authoritative formal legai source rather than the multiple fiq $h$ sources that formerly had to be consulted. The variety of sources had often led to a wide disparity in judgements on similar cases. In addition, the compilation sought to reconcile civil law and Islamic law. ${ }^{32}$

Such a unification has only been attempted a few times in Islamic law, as Bustanul Arifin points out. Previous attempts include: (1) the codification by the Caliph 'Umar ibn 'Abd al-'Azîz; (2) the codification in the 17th century attempted by the Mughal emperor Aurengzeb (Fatâwa Alam Ghiri); (3) the codification in Turkey, known as Majallat al-Ahkâm al-'Adliyah; and (4) the five codifications declared by the President of Sudan, Ja'far Numeiri in September $1983 .^{33}$

Indeed the first attempt to unify Islamic law was originally proposed by Ibn al-Muqaffâ (d. 139/756) to the Abbasid Caliph, Abu Ja'far al-Manshûr (754775). Ibn al-Muqaffâ's proposal was that the Caliph should review the different doctrines, codify and enact his own decisions in the interest of uniformity, and

\footnotetext{
${ }^{2 s}$ Munawir Sjadzali, op.cit. p. 3.

${ }^{29}$ Ahmad Imam Mawardi, 1998, "Socio-Political Background of the Enactment of Kompilasi Hukum Islam di Indonesia", Montreal: Thesis of the Institute of Islamic Studies, McGill University, p. 21.

${ }^{30}$ The special right of guardians allowing a guardian to force a woman under his guardianship to marry without her consent.

${ }^{31}$ Taufiq, 1998, "Pèlaksanaan Undang-Undang Keluarga Islam: Pengalaman Indonesia," (The Application of the Islamic family law of Indonesia), Kumpulan Paper Seminar Serantau Undang-Undang Keluarga Islam dan Wanita, tanggal 9-10 Maret, oleh Institut Kefahaman Islam Malaysia (IKIM), p. 7-13.

${ }^{32}$ Bustanul Arifin, op.cit., p. 114.

${ }^{33}$ Ibid., p. 118.
} 
make this code binding. ${ }^{34}$ After a long process, Mâlik compiled al-Muwattha' in response to this request, but Imam Mâlik rejected the idea that it should be accorded the status of law for all Muslims..

\section{The Demand for the Reform of Indonesian Islamic Family Law}

Although in 1946 a new law of marriage was created, this law was more concermed with administrative than substantive issues. This is why Law No. 1 of 1974 can be seen to be the first law ever introduced in Indonesia dealing with the substantive legal provisions affecting marriage.

As stated above, Indonesians had been clamoring for a new law of marriage well before the birth of Law No. 1 of 1974. The first public demand for the reformation of Islamic family law came from a women's organization in 1928, when the Indonesian Women's Congress (Kongres Perempoean Indonesia: 'Kowani') held a conference, ${ }^{36}$ at which one of the main issues discussed was the shortcomings of the traditional Islamic laws on marriage, particularly as it applies to child marriage, divorce and polygamy. ${ }^{37}$ Stuers mentions three motions approved at this conference and submitted to the Dutch government: (1) that the number of girls' schools be increased; (2) that an official explanation of the meaning of a ta'liq thalâq (conditional or suspended repudiation) be given to the bride at the moment of the marriage settlement; and (3) that a regulation granting a pension to widows and orphans of Indonesian civil servants be established. ${ }^{38}$

Concerns regarding the status of women were voiced by others as well, both individuals and groups. Raden Ajeng Kartini in Java and Rohana Kudus in Minangkabau, West Sumatra, ${ }^{39}$ are perhaps the most famous of the individual complainants. In her letters, Kartini states that there were four aspects of Indonesian marriage law that in practice subordinated women, namely child

\footnotetext{
${ }^{34}$ Joseph Schacht, 1986, Introduction to Islamic Law. Oxford, Clarendon Press, p. 55; N. J. Coulson, 1964, A History of Islamic law. Edinburgh: Edinburgh University Press, p. 52; Marshal G. S. Hodgson, 1977, The Venture of Islam. Chicago: The University of Chicago Press, I: 284-5.

${ }^{35}$ Dawoud Al Alami and Doreen Hinchcliffe, 1996, Islamic Marriage and Divorce Laws of the Arab World. London the Hague, Boston: CIMEL and Kluwer Law International, pp. 35-36; Mazheruddin Siddiq, 1989, Preface to Muwatta' Imam Malik, trans. and notes by Muhammad Rahimuddin. New Delhi: Kitab Bhavan, pp. iv-v.

${ }^{3}$ Arso Sosroatmodjo and A. Wasit Aulawi, Hukum Perkawinan, p. 9; S. Hanifa, "The Law of Marriage," p. 19. The congress was held in Yogyakarta from December 22 to 26, 1928, and included presentations by nearly thirty women's associations. See Stuers, The Indonesian Woman, p. 89.

${ }^{37}$ Arso Sosroatmodjo and A. Wasit Aulawi, Hukum Perkowinan, p. 9. Even before this, however, women's issues had attracted considerable attention. This may be seen from the appearance of the "Surat Kabar Memperhatikan Pihak Perempuan Bumi Putra di Indonesia" (A Review Fostering the Interests of Indonesian Women), a women's weekly magazine, which was first published in 1913: See Stuers, The Indonesian. Woman, p. 62.

${ }^{38}$ Stuers, op.cit., p. 88.

"See discussion, at note 6 .
} 
trairiage, forced marriage; polygamy and the one-sided right of repudiation (hiala $a)^{\text {i0 }}{ }^{0}$ Rohana Kudus; as noted earlier; was direct in criticism of the effects of the child marriage; polygamy and one side divorce (thalâ $q$ ) as well: ${ }^{4 i}$

With regard to women's organizations, the female section of Jong Java, Puteri Indoniesia, with the help of associations such as Persaudaraan Isteri, Persatuan I $\mathrm{Ibu}$; and Wanita Sejati; organized a public meeting in Bandung on October 13,1929 . The object of this meeting was to discuss polygamy and prostitution: Another womlen's organization, Isteri Sedar, held its first congress in Jakarta in June $193 \mathrm{i}$, and adopted resolutions that amounted to a cali for the abolition of polygandy: ${ }^{42}$

Even though İslamie women's organizations were generally in favour of the abolition of polygamy; however one association of Muslim wornen, Serekat Isteri Jakartä; for instäine, organized a meeting one week after Istert Sedar's conngress to protest the resolution adapted by the latter on the issue of polyganiy: ${ }^{43}$ Another exaniple can be found in the fact that, in the second all= Indonesian congress of women, held in Jakarta, $193 \tilde{5}$, Ratna Sari, the prominent leader of the radical Muslin modernist organization $P E R M I$, indirectly accused Soewarini and her Isteri Sedar of having caused an unnecessary division among Indonesian women by their eritieism of polygamy three years earlier. Ratna Sari defended polyganity, and rejeeted the arguments of those who opposed the institution of polygamiy on the grounds that it perpetuated the lower status of fndonesian women $v i s$ a $a i s$ men. First of all, Ratna Sari argued that Islam only permits polygamiy, rather than eneoturaging it. Moreover, Islam imposes conditions that make it difficult to practice polygamy since, among other things, Islain requires that a hisband should be impartial towards all four of his wives. Ratina Sari then explained why Islam allows polygamy, One of the most serious ills of society; she maintained, was prostitution and the keeping of mistresses. Therefore; by allowing men to have more than one wife, Islam in fact provides the best possible solution to this serious ill. Becoming a religiously legal second, third, or fourth wife of a man, for Ratna Sari, was a better and higher position than becoming a prostitute or a mistress. For her, Islam regulated the naturally higher sexual urge of the male sex in the best interests of women. ${ }^{44}$ She argues that critics of polyganiny were not fully considering the practical social issues that inform the debate:

${ }^{40}$ Stuers; op.ctit.; p.

"itibia.

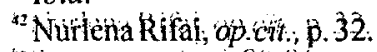

43 stuèrs, ap.cit.; $p 0=91$.

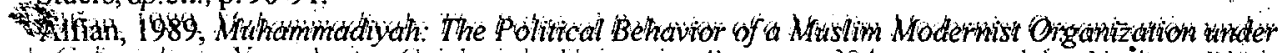

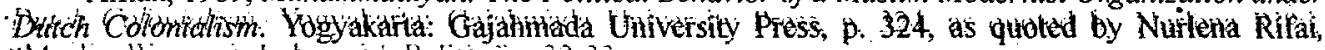

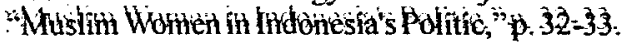


In a belated response to these criticisms, the Dutch government submitted in 1937 to the various associations a draft law entitled 'Ordinance Project for the Regulation of the Matrimonial Legislation of the Muslim Population'. This Marriage Ordinance Project was rejected by all women's organizations. The Islamic organizations and their women's sections rejected it because the Marriage Ordinance Project prohibited the practice of polygamy, and required that marriages be registered in a civil court. The nationalist women's movement opposed the Ordinance Project because they feared that it would cause great divisions not only within women's circles but also among those engaged in the nationalist struggle for the freedom of the nation. ${ }^{45}$

In response to demans by the Indonesian groups, on October 1,1950, the Minister of Religious Affairs of the Indonesian Government appointed a committee, chaired by Mr. Teuku Mohammad Hasan, to draft a Marriage Bill. Two draft Bills were completed in 1952 and 1954. The former of these aimed at the unification of marriage regulations, while the latter was prepared with the aim of recognizing the need for diversity of laws for the different religicus groups. In 1958-59 both Marriage Bills were submitted to and discussed in Parliament, but without any result. ${ }^{40}$

Then in 1960, 1962 and 1963, similar demands were voiced by other women's organizations, respectively the National Congress of the Family Welfare (Musyawarah Nasional Kesejahteraan Keluarga) sponsored by the Ministry of Welfare Affairs; a conference held by the Council on Marriage and Divorce (Konferensi Badan Penasehat Perkawinan dan Penyelesaian Perceraian/ B.P. 4), sponsored by the Ministry of Religious Affairs; and a National Seminar (Seminar Nasional) organized by the Institution of the Establishment of National Law (Lembaga Pembinaan Hukum Nasional /L.P.H.N.) with the help of the Organization of Scholars in Law (Persatuan Sarjana Hukum Indonesia/ Persahi).$^{47}$ Eventually, in December 1967, a draft of the marriage bill was brought to Parliament, but it was not passed because one political party refused to accept it. ${ }^{48}$ Subsequent parliamentary discussions focused on whether the principle of unification of laws (one marriage law for all the different religious groups), or that of diversity of laws (different laws for the different groups), should be the standard applied. ${ }^{49}$ On January 29, 1972, another congress of Indonesian Female Scholars (Ikatan Sarjana Wanita Indonesia /

${ }^{45}$ See Suyatin Katowiyono, "The Awakening of the Women's Movement of Indonesia", in B.B. Heering, (ed.), 1976, Indonesian Women, Some Past and Current Perspectives. Btuyelles: Centre d'etude du sad-est Asiatique et de l'extra line orient, p. 5, as quoted by Nurlena Rifai, "Muslim Women in Indonesia's Politic,"p. 30.

${ }^{46} \mathrm{Hanifa}$ op.cit., p. 20.

${ }^{47}$ Wanjik Saleh, 1976, Hukum Perkawinan Indonesia (Indonesian Marriage Law). Jakarta: Ghalia Indonesia, p. 1-2.

${ }^{48}$ Arso Sosroatmodjo and A. Wasit Aulawi, op.cit., p. 10.

${ }^{49}$ Hanifa, op.cit., p. 20. 
(SWI) demanded reform, ${ }^{50}$ and this was followed by another demand from the Indonesian Muslim Women's Organization on February 22, 1972.

The ISWI symposium raised three important points. The first was that the demand for a new law on marriage was especially urgent; the second that there had been improvements in the relations between different religions, which meant that the substance of the marriage law would not be a problem; and the third that the problem that was holding up reform was the issue of whether diversity or unity should be the rule in this area. Either option, according to ISWI, would be satisfactory. The Indonesian Muslim Women's organization, on the other hand, remarked that the unification of marriage law seemed to be the best choice. $^{52}$

Eventually, on July 31,1973 , the draft marriage bill was proposed to the Parliamentary Congress, based on the unification of laws model. After much heated debate the Bill was finally adopted with several amendments on 22 December 1973, and enacted on 2 January 1974, as the Law of Marriage No. 1 of $1974,{ }^{53}$ which was followed by Government Regulation No. 9/1975 to allow for its implementation. The latter Government Regulation was enacted on April 1, 1975 , and came into force on October $1,1975 .^{54}$

There were four main aims of Marriage Law No. 1 of 1974. First, to restrict or even abolish child marriage; secondly, to restrict polygamy; thirdly, to restrict the one-sided right of repudiation (thalâq); and lastly, to establish equal rights for husband and wife. ${ }^{55}$

Recently, demands for revision of Indonesian marriage law have been made. The majority of the demands come from women's organizations. Kowani for example, list 37 articles of Law No. 1 of 1974 to be revised, and sent their proposals to all the Islamic courts throughout Indonesia for judicial consideration. The issue was again discussed at a conference on October 4, 2000 in Yogyakarta, conducted by a number of organizations the majority of which were, again, women's organizations. The aim of the conference was, in particular, to investigate the possibility of revision of Government Regulation of Marriage Law No. 10 of 1983. The result of the conference was a suggestion to the government to revise not only the Government Regulation of 1983, but also the Marriage Law of 1974. A similar conference was conducted by the Centre of Women's Studies of the Institute of Islamic Studies (IAIN) Sunan Kalijaga

\footnotetext{
${ }^{50}$ Arso Sosroatmodjo and A. Wasit Aulawi, op.cit., p. 22-23.

"Wanjik Saleh, op.cit., p. 2.

${ }^{52}$ Arso Sosroatmodjo and A. Wasit Aulawi, op.cit., p. 22-23.

"Wanjik Saleh, op cit., at 7 .

${ }^{54}$ Hanifa, op.cit., p. 20.

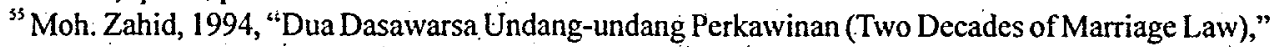
DIALOG: Jurnal Studi dan Informasi Keagamaan, Badan Penelitian dan Pengembangan Agama Depag., No. 39, Th. XVIII, Maret 1994, p. 33-40.
} 
Yogyakarta, on October 6,2000. That conference made lists of suggestion to be considered by the Government in conducting any revision of the marriage law. In addition, there have been writings both in journals and newspapers discussing the subject. Julia Suryakusuma is one examples, who writes of the need for revision of the marriage law of Indonesia, particularly the Government Regulation of $19833^{56}$

\section{Concluding Remark}

It is safe to conclude, therefore, that the role of the Indonesian Wornen Movement in the reformation of Indonesian Islamic family law cannot be doubted. Historical fact shows that ever since its inception, one of the principal demands of the Indonesian Women's Movement has been the reform of Islamic family law. Furthermore, the reform of Islamic family law in Indonesia came not from above but from below, particularly from reform groups and the women's movement, even though some grassroots groups opposed the reforms. The debate concerning the need for revision of Indonesian marriage law is still running, and still largely driven by demands from women's organizations and

- movements.

\section{BIBLIOGRAPHY}

Abdurrahman, 1995, Kompilasi Hukum Islam di Indonesia. Jakarta:AKAPRES.

Afkhami, Mahnaz and Erika Friedl, 1997, Muslim Women and the Politics of Participation: Implementing the Beijing Platform. Syracuse: Syracuse University Press.

Ahmad, Amrullah (ed.), 1996, Dimensi Hukum Islam dalam Sistem Hukum Nasional. Jakarta: Gema Insani Press.

Al Alami, Dawoud and Doreen Hinchcliffe, 1996, Islamic Marriage and Divorce Laws of the Arab World. London, the Hague, Boston: CIMEL and Kluwer Law International.

\footnotetext{
${ }^{*}$ See Julia Suryakususma, 2001; "PP No. 10: Senjata Pamungkas atau Alat Kekuasaan" (The Government Regulation of 1983 is a lethal weapon or a tool of hegemony/power), Kompas, September 20, 2001
} 
Alfian, 1989, Muhammadiyah: the Political Behavior of a Muslim Modernist Organization under Dutch Colonialism. Yogyakarta: Gajahmada. University Press.

Anderson, Norman, 1976, Law Reform in the Muslim World: London: The Athlone Press.

Arifin, Bustanul, 1996, Pelembagaan Hukum Islam di Indonesia: Akar Sejarah, Hambatan dan Prospeknya. Jakarta: Gema Insani Press.

Basri, Hasan, 1986, "Perlunya Kompilasi Hukum Islam," Mimbar Ulama No. 104/x (April).

Beck, Lois and Nikki Keddie, 1978, Women in the Muslim World. Cambridge, Massachusetts: Harvard University Press.

Cammack, Mark, Lawrence A. Young and Tim Heaton, (1996), "Legislating Social Change in an Islamic Society Indonesia's Marriage Law", The American Journal of Comparative Law, vol. 44.

Coulson, N. J., 1964, A History of Islamic law. Edinburgh: Edinburgh university Press.

Hanifa, 1983 "The Law of Marriage and Divorce in Indonesia," Islamic and Comparative Law Quarterly, vol. 3, No. 1 (March, 1983).

Heering, B.B. (ed.), 1976, Indonesian Women, Some Past and Current Perspectives. Btuyelles: Centre d'etude du sad-est Asiatique et de l'extra line orient.

Hodgson, Marshal G., 1977, The Venture of Islam. Chicago: The University of Chicago Press.

Ibrahim, Ahmad Mohamed and Abdul Munir Yaacob; (eds.), 1997, The Administration of Islamic Laws. Kuala Lumpur: Institute of Islamic Understanding Malaysia (IKIM).

Locher-Scholten, Elsbeth and Anke Niehof, eds., 1987, Indonesian Women in Focus: Past and Present Notions. Dordrecht: Foris Publications.

Mawardi, Ahmad Imam, 1998, "Socio-Political Background of the Enactment of Kompilasi Hukum Islam di Indonesia," Montreal: Master's Thesis at the Institute of Islamic Studies McGill University.

Mudzhar, Atho, 1993, Fatwa-fatwa Mejelis Ulama Indonesia: Sebuah Studi tentang Pemikiran Hukum Islam di Indonesia, 1975-1988, ed. Dwibahasa. Jakarta: INIS.

Prodjodikoro, R. Wirjono, 1974, Hukum Perkawinan di Indonesia. Bandung: Penerbit Sumur. 
Ramusack, Barbara N. and Sharon Sievers, 1988, Women in Asia. Indianapolis: Indiana University Press.

Rifai, Nurlena, 1993, "Muslim Women in Indonesia's Politics: an Historical Examination of the Political Career of Aisyah Aminy,". Montreal: Master's Thesis at the Islamic Studies of McGill University.

Saleh, Wanjik, 1976, Hukum Perkawinan Indonesia. Jakarta: Ghalia Indonesia.

Sosroatmodjo, Arso and A. Wasit Aulawi, 1978, Hukum Perkawinan di Indonesia. Jakarta: Bulan Bintang.

Schacht, Joseph, 1986, Introduction to Islamic Law. Oxford: Clarendon Press.

Sears, Laurie J., ed., 1996, Fantasizing The Feminine in Indonesia. Durham \& London: Duke University Press.

Siddiq, Mazheruddin, 1989, Preface to Muwatta' Imam Malik, trans. and notes by Muhammad Rahimuddin. New Delhi: Kitab Bhavan.

Stuers, Cora vreede-de, 1960, The Indonesian Woman: Struggle and Achievements. Netherlands: Mouton \& Co., Printers.

Suryakususma,.Julia. 2001, "PP No. 10: Senjata Pamungkas atau Alat Kekuasaan" Kompas, September 20, 2001.

Taufiq, 1998, "Perlaksanaan Undang-Undang Keluarga Islam: Pengalaman Indonesia," Kumpulan Paper Seminar Serantau Undang-Undang Keluarga Islam dan Wanita, tanggal 9-10 Maret 1998, oleh Institut Kefahaman Islam Malaysia (IKIM)

Zahid, Moh.. 1994, "Dua Dasawarsa Undang-undang Perkawinan .Two Decades of Marriage Law)," DIALOG: Jurnal Studi dan Informasi Keagamaan, Badan Penelitian dan Pengembangan Agama Depag., No. 39, Th. XVIII, Maret 1994. 